Article

\title{
Religious and Political Dimensions of the Kartarpur Corridor: Exploring the Global Politics Behind the Lost Heritage of the Darbar Sahib
}

\author{
Tejpaul Singh Bainiwal \\ Department of Religious Studies, University of California, Riverside, CA 92521, USA; tbain001@ucr.edu
}

Received: 17 September 2020; Accepted: 27 October 2020; Published: 29 October 2020

check for updates

\begin{abstract}
The 550th birth anniversary of Guru Nanak and the construction of the Kartarpur Corridor has helped the Darbar Sahib at Kartarpur in Pakistan gain global attention. In 2019, thousands of Sikhs embarked on a pilgrimage to Pakistan to take part in this momentous occasion. However, conversations surrounding modern renovations, government control of sacred sites, and the global implications of the corridor have been missing in the larger dialogue. Using historical methods and examining the Darbar Sahib through the context of the 1947 partition and the recent construction of the Kartarpur Corridor, this paper departs from the metanarrative surrounding the Darbar Sahib and explores the impact that Sikhs across the globe had on the "bridge of peace", the politics behind the corridor, and how access to sacred Sikh spaces in Pakistan was only partially regained.
\end{abstract}

Keywords: Kartarpur Corridor; Guru Nanak; Imran Khan; Navjot Sidhu; diasporic Sikhs

\section{Introduction}

In November 2018, the decision of the governments of Pakistan and India to open the Kartarpur Corridor across the river Ravi-linking Dera Baba Nanak Sahib (in India) and Gurdwara Darbar Sahib in Kartarpur (in Pakistan) - marked the possible beginning of a new era of cooperation and a symbolic movement in the shared cultural history of the Punjab. The two historic gurdwaras are roughly six kilometers apart and share a connection to Guru Nanak, the founder of the Sikh religion, but the international border created by the partition of India in 1947 separated them, and simultaneously politicized their access. From a global perspective, the Kartarpur Corridor has been celebrated for its ability to become a "bridge of peace" between the two neighboring countries, which have had a history of conflict. Following his visit to the Darbar Sahib in February 2020, UN Secretary-General António Guterres called the Kartarpur Corridor a "corridor of hope" and Darbar Sahib "the best symbol" for peace and "interfaith harmony" (United Nations News 2020). While the Kartarpur Corridor has received much attention from the media, it has failed to gain any traction in the scholarly world outside of one article (Singh 2019a). The author suggests that, while there is certainly an opportunity for the corridor to serve as a gateway for interfaith harmony, the "strategic imperatives" of India and Pakistan "remain the same: to manage, regulate and control access to Sikh sacred shrines, the existence of which radically disrupts the new sacred geographies of post-1947 Indian and Pakistani nationalisms" (Singh 2019a, p. 10). This paper explores the history of, and prospects for, the Kartarpur Corridor. Using primary sources, interviews, and historical methods, the purpose of this essay is to provide an alternative narrative of the Kartarpur Corridor in which historical documents are used to investigate (1) the work done by diasporic Sikhs, (2) the various agendas behind the corridor, and (3) why access to sacred Sikh spaces in Pakistan may have only been momentarily regained. This work uses important sources not available in Singh (2019a), and is, therefore, able to offer a more nuanced and complex analysis in some respects. 
First, this paper discusses the social and historical context of the Darbar Sahib, Kartarpur from Guru Nanak's period in the early 16th century to the present day. It is crucial to understand the significance Kartarpur has amongst Sikhs, as it is the site where Guru Nanak established a settled and lasting community of followers. More than four centuries later, the partition of India introduced an international political boundary that had never before existed in that geographic location. Over the years, the political dynamic between India and Pakistan has shaped the development of the Kartarpur Corridor leading to an oscillation between access and lack of access. Second, we analyze the role diasporic Sikhs have had in preserving the heritage of the Darbar Sahib and other Sikh heritage sites in Pakistan, introducing significant new evidence. The typical media narrative accompanying the Kartarpur Corridor places former Punjab Minister Navjot Singh Sidhu (India) and Prime Minister Imran Khan (Pakistan) as the main contributors in preserving and gaining open access to historical Sikh sites in Pakistan. However, this narrative erases the long history of Sikhs, especially diasporic Sikhs since the 1970s, in seeking access to Sikh sacred sites in Pakistan, along with vital efforts to repair and restore neglected sites. Finally, this paper rethinks the "bridge of peace" and investigates the various agendas behind the corridor from multiple perspectives. Since partition, India and Pakistan have had many opportunities to fulfill the Sikh community's demand for open access to Sikh heritage sites, but have repeatedly refused to do so due to ongoing political tensions. A thorough analysis of these key moments in history will demonstrate how the corridor is likely an isolated event in which access to sacred Sikh spaces in Pakistan may have only been momentarily regained.

\section{Background on Kartarpur and Darbar Sahib/Partition of Punjab}

Guru Nanak was born in 1469, had a spiritual revelation about 30 years later, and embarked on extensive travels of spiritual exploration. Following his extensive travels, Guru Nanak settled down near the river Ravi at Kartarpur in 1519. This period in Kartarpur was "the most important period of his life in terms of his posthumous influence" (Grewal 1969, p. 284). It was within Kartarpur that Guru Nanak truly assembled the Sikh "panth" (community) as disciples would visit on a regular basis. There were three daily activities for disciples: (1) devotion, both individual and communal; (2) instruction by Guru Nanak; and (3) daily labor, which coincided with the three features that constituted the ideal person for Guru Nanak_-"nam"-Divine Name/relation with the Divine, "dan" — charity/relation with society, and "ishnan" purity/relation with the Self (Singh 2006, p. 177). Not only was Kartarpur a religious site for the Sikh community, but it became the political and social hub as Guru Nanak used his platform in Kartarpur to denounce contemporary politics, society, and religion (Grewal 1990, p. 28). In the last two decades of his life, Guru Nanak settled down at Kartarpur where he imparted regular instruction to his now well-defined community of followers. He preached to not only focus on interior devotion, but to pursue honest occupations for livelihood, and combine piety with worldly activity. Before his death, Guru Nanak appointed Guru Angad as his successor and bowed before him (Guru Granth Sahib, pp. 966-67). This proved to be extremely important as Guru Nanak made "a clear statement of the primacy of the message over the messenger", which was the first step in ensuring the formation of the present-day Sikh community (Singh 2006, p. 183).

Although Kartarpur was the site of the first well-established Sikh community, it has always been engulfed in territorial disputes. Shortly after Guru Angad was appointed as Guru Nanak's successor, a new center was established in Khadur. The center was shifted from Kartarpur to Khadur due to the legality of heirs and ownership as Guru Nanak's son, Sri Chand, took control of Kartarpur (Grewal 1990, p. 47). With Sri Chand being the founder of the Udasi sect, Kartarpur remained in Udasi control for several centuries (ibid., p. 117; Oberoi 1994, p. 124). During the Sikh Empire, this group received "revenue-free land-grants" as they established settlements in areas associated with the Sikh Gurus (Oberoi 1994, pp. 123-27). Under the British Raj, the Waqf Act of 1861 allowed the British government to officially transfer the care of gurdwaras to non-Sikhs while allowing Hindus and Muslims to care for their respective places of worship (Petrie 1970). As sacrilegious acts were committed at several gurdwaras, Sikhs ultimately regained control of Darbar Sahib, Kartarpur and 
other gurdwaras following the Sikh Gurdwaras Act of 1925. Darbar Sahib was severely damaged due to the Ravi River flooding at the beginning of the century and it remained neglected until the Maharaja of Patiala, Bhupinder Singh, donated Rs. 135,600 to have it restored in the 1920s (Pannu 2019, p. 383). Unfortunately, even after the Sikh Gurdwaras Act of 1925 and the restoration by the Maharaja of Patiala, Sikh control of Darbar Sahib, Kartarpur did not survive.

As noted earlier, Kartarpur fell on the Pakistan side of the new international boundary. In addition to the violence of partition, an immediate and still-present dispute over Kashmir, bordering Punjab to the north, guaranteed that the border would not be an open one-in fact, quite the opposite. Later in the paper, specific episodes of this troubled history are described, in the context of how they affected access to Sikh sacred sites now in Pakistan.

Sikhs suffered greatly with the partition of India in 1947—not only were lives and property lost, but they were also deprived of open access to more than 75 percent of their most historically significant gurdwaras, including the birthplace of Guru Nanak and the Sikh faith (Pannu 2019, p. 13). Shortly after the partition and realizing the loss of access to key historic sites, the Akali Dal demanded an "immediate resolution of the dispute between India and Pakistan over the land of gurdwaras at Nankana Sahib and Kartarpur" on 4 January 1948 (Bharti 2018). Several months later, during the annual Diwali gathering in November 1948, Jathedar Mohan Singh Nagoke of Akal Takht Sahib relayed the following message to the Sikh community in Amritsar:

India, our country, has become free from slavery of the British, and the Sikh community has made tremendous sacrifice for this freedom. In this free India, we are to keep the Sikh community ever in high spirits and lead the country to its acme heights of progress. As such, the Sikh congregations should pay special attention to the following matters during the next year:

(1) To pray to the Almighty for freedom of the Gurdwaras and the Indian women left back there in Pakistan (Singh 2012, p. 79).

Recognizing that the partition resulted in Sikhs losing access to gurdwaras and other historical sites in Pakistan, members of the community began drafting lines to include in "ardas" (prayer). By the beginning of 1952, the Shiromani Gurdwara Parbandhak Committee (SGPC) agreed upon lines written by Sardar Joginder Singh (Singh 2019b). On 25 January 1952, the Akal Takht Sahib released the following "hukamnama" (order):

This Order from Sri Akal Takht Sahib is meant for compliance of the entire Sarbat Khalsa and the Sevadars of all the Gurdwaras that the following words be taken as mandatory for inclusion in the formal Ardas.

He Akāl Purakha Apne Pantha De Sadā Sahā̄ Dātāra Jīo, Srī Nankāṇā Sāhiba Te Hora Gurduāriām Gurdhāmāim De Jinhāim Tờ Pantha Nūim Vichoriā Giā Hai, Khulhe Darshana Dīdār Te Sevā Samibhāla Dā Dān Khālsā J̄̃ Nūim Bakhasho II

Hey Akal Purakh! You ever being gracious to your Panth! Kindly bestow the boon of your benevolence upon your Khalsa in kindly granting the privilege of free glance, glimpse, service, and security of Sri Nankana Sahib and other Gurdwaras and Guru-shrines which have been separated from the Panth (Singh 2012, p. 80).

As the global Sikh community began doing ardas for open access to historical sites in Pakistan, a secret pact made by India's Minister for Home Affairs, Govind Ballabh Pant, and Pakistan's Prime Minister, Sikandar Mirza, in 1955, known as the Pant-Mirza Agreement to Prevent Border Incidents and Protect Places of Worship, ignored the plight of Sikhs (Lal 2014). This meeting highlights the ignorance of both governments as control of these historical gurdwaras became a negotiable item for them despite attempts made by the SGPC and the Sikh community to retain control of and access 
to gurdwaras in Pakistan (Pannu 2019, p. 13). The control and management of the Darbar Sahib, Kartarpur and other historical Sikh sites were officially lost with the pact of 1955-exactly 30 years after gaining control of gurdwaras-as they were considered to be "evacuee properties" (Lal 2014). Realizing the loss Sikhs suffered with the Pant-Mirza Agreement, in 1959, the SGPC and Chief Khalsa Diwan sent a letter to the Indian prime minister demanding that "India should get back the gurdwara land," which the Congress government in Punjab opposed (Bharti 2018). With the 500th birth anniversary of Guru Nanak in 1969, Prime Minister Indira Gandhi promised to fulfill the demand made by Sikhs a decade earlier. The promise included a land swap for the Darbar Sahib, Kartarpur and free visas for Sikh pilgrims wishing to visit Nankana Sahib (ibid., 2018). As hostilities between India and Pakistan were heightened over the years due to the Indo-Pakistani War of 1971, hopes of access to historical Sikh sites in Pakistan faded away. However, in September 1974, with new leadership in Pakistan, representatives from both governments met in Islamabad to further discuss pilgrimage to religious sites. The Protocol on Visits to Religious Shrines of 1974 not only granted non-discriminatory visits from one country to another for such visits but ensured that sites were properly maintained (Ministry of External Affairs n.d.). Although the Protocol succeeded in including eleven historical Sikh sites-Gurdwara Sri Nankana Sahib (Sheikhupura); Gurdwara Sri Panja Sahib (Rawalpindi); Samadhi of Maharaj Ranjit Singh (Lahore); Gurdwara Sri Dera Sahib (Lahore); Gurdwara Janam Asthan (Lahore); Gurdwara Deewan Khana (Lahore); Gurdwara Shaheed Ganj, Singhanian (Lahore); Gurdwara Bhai Tara Singh (Lahore); Gurdwara of Sixth Guru, Mozang, (Lahore); Birthplace of Sri Guru Ram Das (Lahore); Gurdwara Cheveen Padshahi, Mozang (Lahore)-Darbar Sahib, Kartarpur was excluded because of the sensitivity of the border area controlled by Pakistan Army's Rangers. (Express News Service 2018). While the Protocol on Visits to Religious Shrines of 1974 was a minor success for the global Sikh community and gaining access to historical sites in Pakistan, India refused to communicate with Pakistan in regard to Darbar Sahib over the next few decades with the development of transnational Sikh political aspirations and the rise of the Khalistan movement. The impact of the Khalistan movement and lack of cooperation to provide access to Darbar Sahib from the Indian government is discussed in further detail later in subsequent sections. Meanwhile, the Darbar Sahib continued to deteriorate. Based on memories of local people, throughout the 1980s and the 1990s, the abandoned gurdwara was a refuge for drug addicts to escape the "gaze of civilization" (Khalid 2017a). With the establishment of the Pakistan Sikh Gurdwara Prabandhak Committee (PSGPC) in April 1999, control and management of several Sikh sites in Pakistan finally returned to Sikhs. However, while the caretakers of the gurdwaras were Sikhs, the first chairman of PSGPC was the former chief of Pakistan's intelligence agency, Inter-Services Intelligence (ISI), Lieutenant-General Javed Nasir (Goyal 2019). Despite this, the majority of Sikhs were still unable to visit the Darbar Sahib. With the tension between the bordering countries and their inability to visit the Darbar Sahib, Sikhs in India resorted to desperate measures to gain "darshan" (glimpse) of the politicized historical site:

The gurdwara can today be seen through binoculars from across the Indian side of the international border, even though the tall elephant grass on the banks of Ravi sometimes blocks the view. Devotees on the Indian side often step onto a 10-foot platform built in the town of Dera Baba Nanak (Gurdaspur District) to gain a darshan (glimpse) of the Darbar Sahib, Kartarpur, where Guru Nanak spent the last 18 years of his life. The Border Security Force guarding the platform kindly provides curious visitors with binoculars to view the site from afar (Pannu 2019, p. 383).

With the Kartarpur Corridor, the times of gazing at the Darbar Sahib, Kartarpur from a distance are gone. The 550th birth anniversary of Guru Nanak was another milestone in Sikh history as the global Sikh community finally had the opportunity to visit the birthplace of the Sikh community. 


\section{The Role of Diasporic Sikhs in Reviving the Lost Heritage of Darbar Sahib}

The popular understanding of efforts to preserve and maintain Sikh heritage sites in Pakistan is linked with Navjot Sidhu's visit to Pakistan in 2018. Despite this metanarrative of media and current elected officials, the initial efforts to preserve and maintain Sikh heritage sites in Pakistan began much earlier. Throughout the entire process, several key individuals and organizations have remained unrecognized or have been forgotten due to their modesty, putting "seva" (selfless service) above all else. However, the Sikh panth may have never gotten the opportunity to make this pilgrimage if it was not for these unofficial actors. Over the past five decades, the global Sikh community has actively engaged with the government of Pakistan. This section will trace the seva initiated by diasporic Sikhs and their efforts to preserve and maintain these sites. Despite India and Pakistan's unstable relationship since partition, the global Sikh community has been actively opening channels of communication with the government of Pakistan in an attempt to answer the decades-long wish for the preservation of and open access to historical Sikh sites in Pakistan. The rocky relationship between the neighboring countries has always been an obstacle for Sikhs in Punjab and other areas in India to create a meaningful dialogue with Pakistan, which allowed the work done by diasporic Sikhs to be more successful. Four distinct major episodes are described in this section. Due to their dedication to seva, the individuals and groups in these episodes have sometimes been forgotten or unrecognized. To historicize these narratives, ensure their work is recognized, and deepen our historical understanding, this section is largely formed through personal conversations with diasporic Sikhs. Furthermore, this section will show that there are several motivating factors within diasporic Sikhs that draw them to focus on sites in Pakistan including those who wanted Sikhs to gain unfettered access to Sikh heritage sites (such as the Sri Nankana Sahib Foundation and the Guru Nanak Shrine Fellowship) and those that had family connections in the Pakistani Punjab (such as Dr. Dalvir Singh Pannu).

\subsection{Sri Nankana Sahib Foundation}

The communication between Sikhs and Pakistani government officials to preserve Sikh sites launched in the mid-1970s with the creation of the Sri Nankana Sahib Foundation with a well-connected Washington-based Sikh, Ganga Singh Dhillon. Through his connections, Dhillon was able to form a relationship with President Muhammad Zia-ul-Haq and his Minister for Political Affairs, Chaudhry Zahoor Elahi (Badhwar 1981). In 1975, Dhillon organized the first "jatha" (group) of 25 Sikhs to visit historical Sikh gurdwaras in Pakistan. He notes that "their condition was deplorable, specially what I saw, in Lahore in Nankana Sahib. These are our holiest of places. Except for Batala where Guru Nanak was married, there is no physical or architectural history of Nanak in India. It is all in Pakistan" (ibid., 1981). After seeing the condition of these sites, Dhillon formed the international Sri Nankana Sahib Foundation "to construct, renovate, repair and maintain Gurdwaras, historical and religious buildings and shrines and affiliated premises of Guru Nanak Dev Ji and the other Nine Sikh Gurus" in Pakistan (Sandhu n.d.). Furthermore, the foundation wanted to ensure that Sikhs across the globe had the opportunity to visit these historical sites that were stripped away during the partition. Charan Singh Sandhu (commonly referred to as Charan Singh "Sangatpura"), a prominent leader amongst the Sikh community in Hong Kong from the 1970s to the early 2000s, joined Dhillon and the Sri Nankana Sahib Foundation during its early stages. Following Charan Singh's lead, several members of the Hong Kong Sikh community became lifetime members of the foundation to ensure open access and the preservation of Pakistani gurdwaras, including Gurmukh Singh Dhillon, Gurbhej Singh, Daljit Singh Gill, Sucha Singh "Chandigarh", and Gurcharan Singh Bhuchar (Sandhu n.d.). Upon joining the foundation, Charan Singh led several jathas on pilgrimages to visit various gurdwaras, including, but not limited to, Gurdwara Panja Sahib Hassanabadal; Gurdwara Bhai Joga Singh Peshawar; Gurdwara Janam Asthan Nankana Sahib; Gurdwara Sacha Sauda Farooqabad, once known as Chuhrkhana; Gurdwara Darbar Sahib Kartarpur; and the house of Bhai Lalo Eminabad (Bhuchar 2020). Not only did the Hong Kong Sikh community make pilgrimages to historic gurdwaras, but also financially supported the efforts to preserve Sikh heritage sites in Pakistan. During their first visit, the Hong Kong sangat raised "6 lakh 
$(600,000)$ rupees" for various projects in Nankana Sahib_-including constructing a school building for the local community (ibid., 2020).

Over the years, Charan Singh made several trips to Pakistan with jathas from across the globe (See Figure 1). While the Sri Nankana Sahib Foundation focused on these trips and assisting in small scale renovation projects in Pakistan from the 1970s through the early 2000s, large-scale renovations for the Darbar Sahib, Kartarpur began in the 1990s.

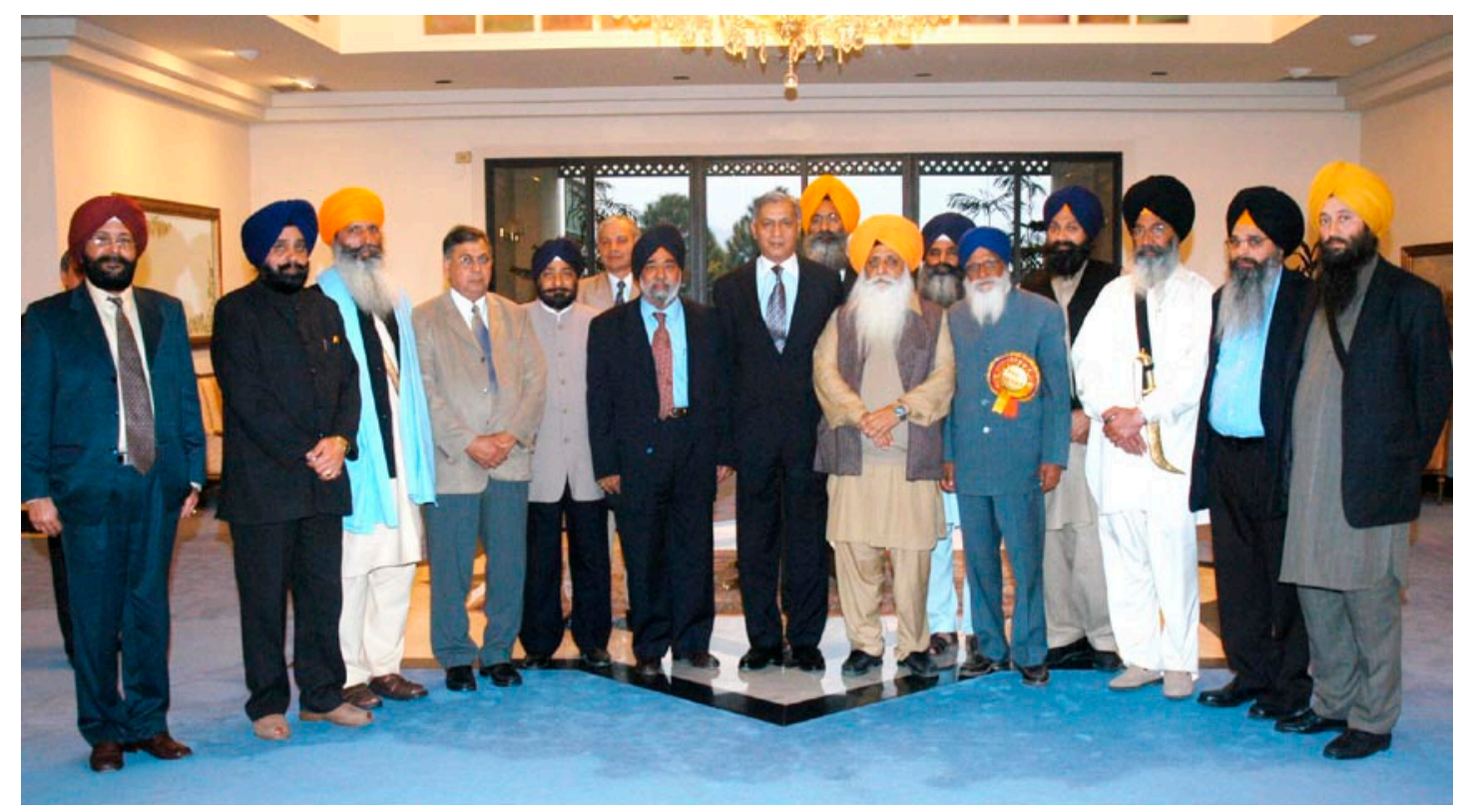

Figure 1. A Sikh delegation with Prime Minister Shaukat Aziz at the prime minister's house on 29 November 2004. Charan Singh Sangatpura, the third from the left in the orange dastar (turban), has led several delegations since the 1980s.

\subsection{Guru Nanak Shrine Fellowship: The Beginning of the Renovation Process}

The renovation of the Darbar Sahib, Kartarpur is a story of two men: Dr. Gurcharanjit Singh Attariwala, a Canadian-based ophthalmologist, and Lieutenant General (Retired) Jahandād Khan, a general in the Pakistan army and former governor of Sindh. The two first met when General Khan was traveling across Canada and the United States to raise funds for his first Al-Shifa eye hospital in Rawalpindi in the late 1980s. The hospitals were dedicated to treating millions with the highest level of care, at low to no cost. The purpose of the Al-Shifa hospital motivated Attariwala, South Asian professionals in Calgary, and the Sikh community to help General Khan's efforts. Through Operation Eyesight, a Calgary-based charity dedicated to eliminating avoidable blindness, the three affinity groups mentioned above helped with equipment, and also helped him build a medical lab to produce drugs for eye-related conditions. They raised a substantial amount of money for General Khan and established a relationship with the Al-Shifa Trust. Through the years, Attariwala and General Khan had exchanged many letters and become good friends (Attariwala 2019b).

In 1992, Attariwala went to Pakistan for the first time with his wife, Mrs. Gurdev Kaur Attariwala, since fleeing Rawalpindi as a teenager during partition. The impetus to visit Pakistan came from two events: a conference being held in Karachi that coincided with an invitation to attend the marriage of a friend's son. It was during this trip where he was informed of "Pakistan's Darbar Sahib". In an interview with his daughter, Parmela, Attariwala shares, "We went to attend the wedding of Dr. Mahmood's son and stayed with Mahmood's wife's nephew, Fazal—in Lahore. And [Fazal] asked me if I had been to Darbar Sahib. I said, 'Yes in Amritsar'. He said, 'No, no, no: in Pakistan'” (Attariwala 2019b). 
With this, Fazal arranged to take them to visit Darbar Sahib, Kartarpur. As the Attariwalas traveled to Kartarpur from Lahore, they noticed signs which read "Darbar Sahib, Kartarpur" all along the highway. Upon reaching the Darbar Sahib, they saw the gurdwara in ruins. Attariwala recalls:

It was all damaged. There were no windows, no doors; no, nothing. There was a big slab [inside] with a green sheet. I don't know. I presume the green sheet covered the platform where they held parkash of Guru Granth Sahib. OR this is where Guru Nanak was cremated. We don't know. We had no guidance there. There was no one. No one knew anything; no one to tell us anything. And there was a gas lamp—dried up —and a red rose [on the ground]. So, there was nothing (Attariwala 2019b; See Figure 2).



Figure 2. This photo was taken by Dr. Attariwala showing the interior of Darbar Sahib during his visit.

The building was in awful condition, the tombs were destroyed, the ceiling was damaged, and there was no road to get to the Gurdwara building. Fortunately, Attariwala's visit to Pakistan allowed him to form relationships which set into motion a series of events that led to recent discussions to open the border to Sikh pilgrims (Attariwala 2019a). Returning to Canada after his visit to Kartarpur, Attariwala was inspired to restore the gurdwara. He put together a working group through which they gathered funds dedicated to the restoration of the Darbar Sahib, Kartarpur. Mobilizing Sikhs in the diaspora, Attariwala and his colleagues established the Guru Nanak Shrine Fellowship. The organization created brochures with images of the gurdwara in ruins that also highlighted the Pakistani government's willingness to contribute funds to the restoration of the gurdwara. Attariwala acknowledges that the Pakistani government's contribution to the restoration of the historical gurdwara would not have taken place without the influence of General Khan. A letter written by General Khan to the Minister for Religious Affairs, Raja Muhammad Zafar Ul Haq, on 12 February 1998 reads:

\section{My dear Raja Sahib,}

There is a large sized Sikh Community in Calgary (Canada) which I have been visiting every alternative year since 1990, in connection with mobilization of donations to Al-Shifa Trust. During my recent visit to Calgary, the community leaders had expressed their serious concern about (the) state of maintenance and repairs of their Gurdwara in Narowal, which is one of their very sacred shrines.

I was specially asked by these community leaders to request authorities to kindly get this Gurdwara repaired as a matter of highest priority because a large number of Sikh devotees from all over the world 
visit this Gurdwara every year. I was also told by these Sikh leaders that they would be prepared to contribute some of the cost of the repairs if shortage of funds is the main constraint.

I shall be grateful if you could kindly issue instructions to authorities to attend to this genuine request of Sikhs, on a priority basis.

General Khan proved to be a key partner as he worked tirelessly throughout the entire restoration process of Darbar Sahib. Although it was Attariwala's visit in the early 1990s that eventually led to the restoration, the letters General Khan sent to several ministers marked the official start of conversations regarding renovation. General Khan's influence amongst elected officials in Pakistan was enough to persuade the government to not only agree to the restoration, but also contribute Rs. 7.5 lakhs $(750,000)$ to the project. In a letter from General Khan to Dr. Attariwala dated 26 January 1999, Dād Khan writes:

Ever since my return from Calgary in 1997, I have been pursuing the case of Narowal Gurdwara. There are three ministers involved in this case and hence all this delay. However, I am glad to inform you that restoration/renovation process has now started and Chairman Evacuee Trust (Lt Gen Javed Nasir) has assured me that it will be completed at the cost of Rs 7.5 lakhs (Pakistani rupees), which he has sanctioned for this project... I understand the 300-year anniversary is due some time at the end of this year, and if you find it possible, please come on this occasion. General Javed will personally accompany you and show you the progress of work and future plan. Please rest assured, we will do everything possible to protect this holy place.

After roughly 50 years of neglect, the Pakistani government suddenly became interested in Kartarpur and its gurdwara due to Attariwala's friendship with General Khan. By the end of the century, the renovations were complete. On 19 November 1999, the Sikh Panth witnessed the first Parkash since the partition. This momentous occasion was attended by Sikhs in the diaspora (including Attariwala), "gianis" (religious leader) from Nankana Sahib to perform the kirtan, a local member of parliament (Chaudhry Anwar Aziz), and local Muslims and Sikhs (See Figure 3). Many locals wished to be a part of the momentous occasion but settled for standing outside the open doors, which allowed Sikhs from the diaspora and nearby villages to congregate in the main hall. Following the divan, Muslims and Sikhs joined together for langar as the occasion came to an end. By the time of the Gurdwara's reinauguration, the Pakistani government had undertaken the restoration of the outside of the building and superficially cleaned its interior. They had also begun to construct roads to the temple.

The work started by Attariwala and General Khan, in the 1990s, to renovate Darbar Sahib had global significance, leading to a movement to restore a heritage site that represented universal human values and ideals (See Figure 4). 


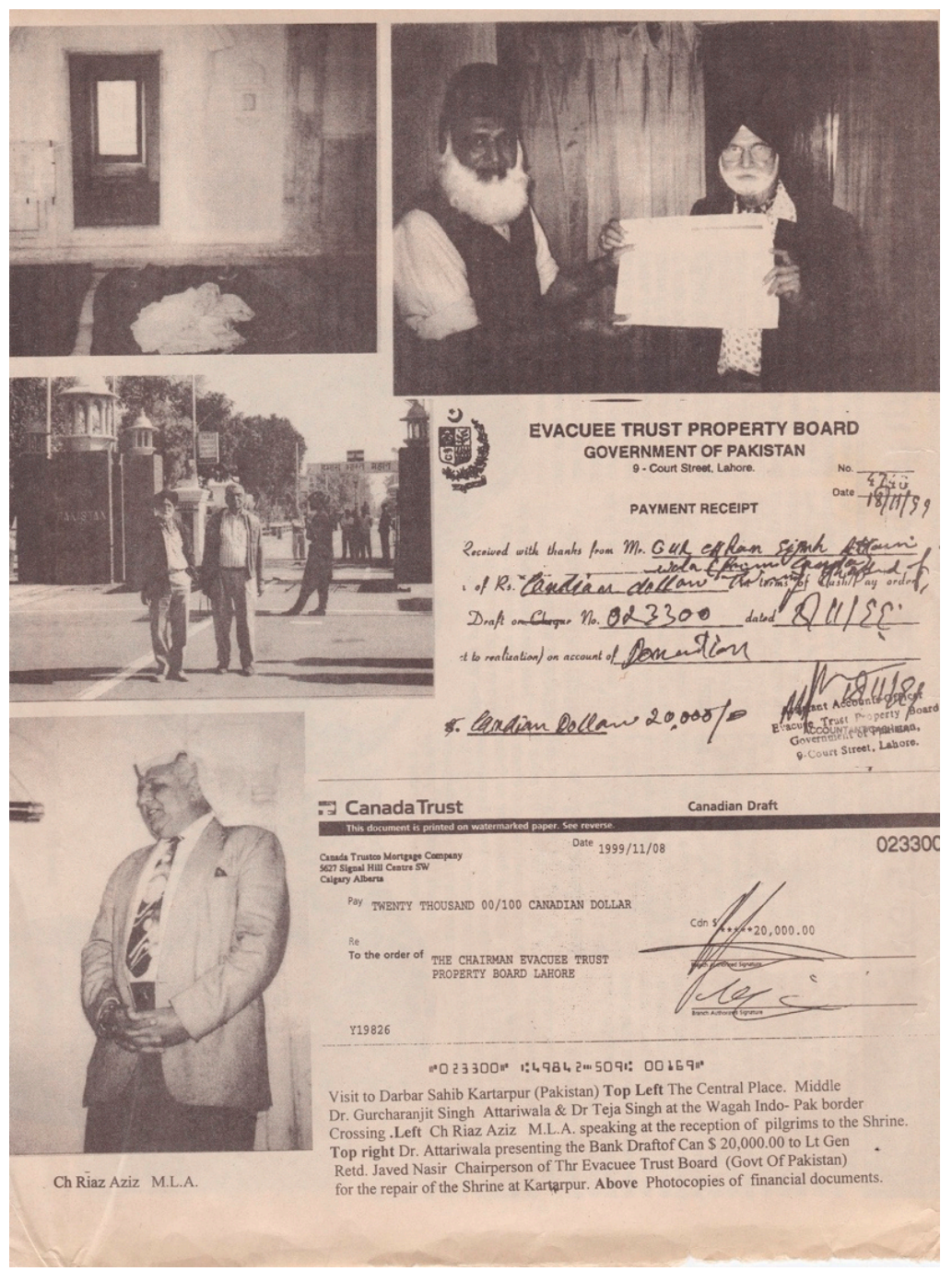

Figure 3. A January 2000 newspaper shared highlights from Dr. Attariwala's visit to the November 1999 occasion. Top left: A picture taken by Dr. Attariwala during his initial visit in 1992 of the desolate interior in the abandoned Gurdwara. Middle left: Dr. Attariwala and Dr. Teja Singh crossing the Wagah border into Pakistan. Bottom left: Local member of parliament who attended the inaugural kirtan and addressed the sangat. Top right: Dr. Attariwala presenting a check to the minister in charge of shrines left by Indians in Pakistan, General Naser. Bottom right: Receipt and check of $\$ 20,000$ Canadian dollars raised by the Guru Nanak Shrine Foundation. 


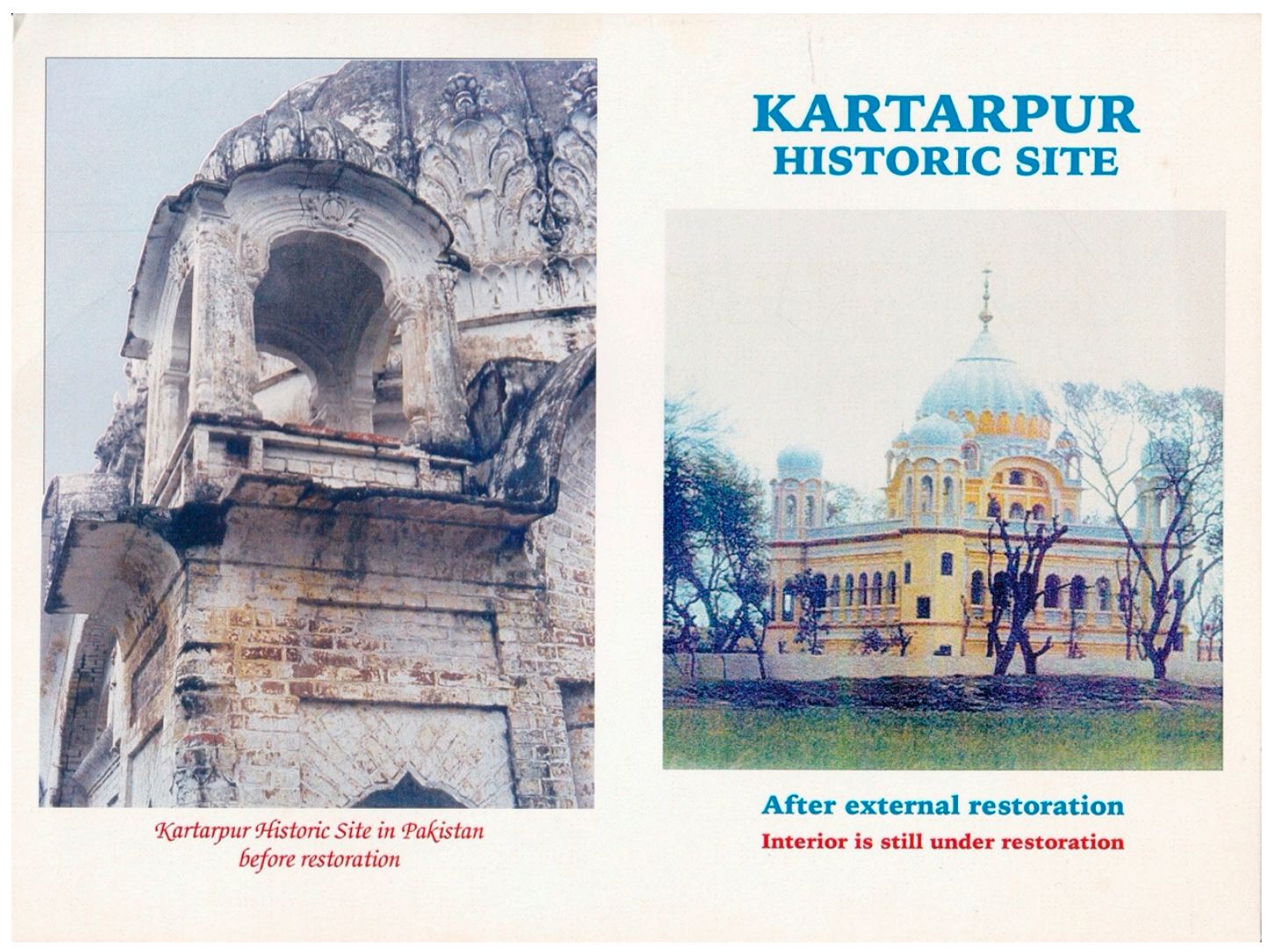

Figure 4. Side by side photos of Darbar Sahib, Kartarpur from 1992 (before restoration) and 1999 (post external restoration).

\subsection{Digital Preservation of Historical Sikh Sites in Pakistan}

Over the years, there have been several gurdwaras that were renovated and preserved, yet the majority of Sikh heritage sites in Pakistan have been neglected. While some Sikhs have been working to physically preserve and ensure open access to historical Sikh sites in Pakistan, others have taken a different approach. This section explores the meticulously documented digital preservation work of historical Sikh sites by two diasporic Sikhs-Amardeep Singh, a former corporate businessman from Singapore, and Dr. Dalvir Singh Pannu, a dentist from the Bay Area region of California. Despite coming from different backgrounds, both diasporic Sikhs shared a passion to unearth the narratives of Sikh heritage sites in Pakistan that has paved the way for preservation projects in recent years.

In 2014, at a time when the knowledge of gurdwaras in East Punjab was extremely limited, Amardeep Singh started documenting the broader Sikh legacy remnants in Pakistan. Singh had hoped to shed light on the subject as "Sikhs and Pakistanis were themselves ignorant about the expanse of the subject" (Singh 2020). With minimal support from community organizations, Singh published his exploration of Sikh heritage sites across 126 cities and villages in Pakistan in the form of two books—Lost Heritage: The Sikh Legacy in Pakistan (Singh 2016a) and The Quest Continues, Lost Heritage: The Sikh Legacy in Pakistan (Singh 2017). The relationship with Pakistani citizens during his journey was fulfilling, but Singh was forced to take risks to accomplish certain goals due to the restrictions of the government of Pakistan. He shared that "if one wants to reach deep, in areas where foreigners are not permitted, then navigating through the establishment is the biggest challenge" (Singh 2020). However, the risks were crucial in order to capture visual documentations of Sikh heritage sites and inform the government of their capability to increase tourism. In 2019, Singh shifted his entire focus to the multi-episode documentary on Guru Nanak's travels across nine countries. Although the majority of the landmass of the nine countries Guru Nanak traveled across was inaccessible to film by a foreigner, 
Singh was resilient and successful. While this is a painful and slow process, the "first step to influence change is documentation to arouse curiosity" (Singh 2020). Alongside informing the government of Pakistan, Singh also wanted to educate the broader Sikh community on the Sikh legacy in Pakistan beyond the few functional gurdwaras. With physical sites rapidly deteriorating, Singh views his works as a "chase against time" (Singh 2020). The choice to digitally preserve these sites, including Darbar Sahib, was not only because they influenced change, but the fear that there would be nothing left to preserve without quickly documenting it in print and documentaries. Due to the broader community engaging with Singh's work, abandoned gurdwaras have been announced for maintenance including Chowa Guru Nanak Gurdwara in 2019.

In the same year, Dr. Dalvir Singh Pannu published a book on Sikh heritage sites in Pakistan titled The Sikh Heritage: Beyond Borders (Pannu 2019) to commemorate the 550th birth anniversary of Guru Nanak. The motivation to begin the project to digitally preserve the historic sites in Pakistan came from a visit to his ancestral home in Pakistan in 2008 combined with his longstanding passion to research Sikh historical and religious sites and personal conversations with several of his patients who shared a connection to heritage sites in Pakistan (Pannu 2020). In 2010, Pannu published his twelve-episode travelogue to Pakistan in a local newspaper which received an overwhelming response and led to him building a field team in various parts of Pakistan. Over the next 10 years, he was able to create an extensive digital repository, covering more than 270 Sikh heritage sites from the mountains of Khyber Pakhtunkhwa to the deserts of Balochistan (Pannu 2020). Building one of the most extensive bibliographic lists for the Sikh heritage in Pakistan, Pannu's work has received attention at leading academic institutes in Pakistan. The rare artwork, as displayed in the high-resolution photographs, has given Pannu's work exposure in the internationally acclaimed journal The Architectural Historian, which will only help raise global awareness about the Sikh art in these abandoned buildings in Pakistan. He has also put particular focus on drawing parallels between Janamsakhis and Sufi traditions in his book, giving an analytical approach to handle the sensitive conversation among the faithful and skeptics. The decision to digitally preserve these sites and publish a book rather than raising funds to preserve the physical structures was intentional as Pannu wanted the local community, the government of Pakistan, and others who share a personal connection to the sites to take interest and the initiative to preserve these sites (Pannu 2020). Pannu views his book as an educational and motivational guide which gives these different stakeholders the sources to accomplish this goal and it has been proven to be successful. Gurdwara Mal Ji Sahib, Kanganpur (Kasur District) is one of many sites that stakeholders have committed to preserve following a conversation with Pannu. The digital preservation of Sikh heritage sites-by Singh and Pannu—allows the global Sikh community to gain a darshan of these sites as many may not be able to visit them for several different reasons.

\subsection{Combined Efforts to Promote Sikh Tourism and Preservation in Pakistan}

In June 2019, the momentum coming from the 550th birth anniversary of Guru Nanak and the Kartarpur Corridor resulted in UK businesses pledging 500 million pounds for religious tourism projects in Pakistan. In a meeting with the chairman of the Pakistan Tourism Board and special assistant to Prime Minister Imran Khan, Sayed Zulfiqar Bukhari, Peter Singh Virdee, and several other British Sikhs made the financial commitment to establish a trust to help renovate gurdwaras in Pakistan (Shah 2019). In order to ensure the trust had global representation, the group established the Guru Nanak Global Sewa Trust (Sikh Channel 2019). The commitment to invest in religious tourism projects was reciprocated by Bukhari as he assured the Sikh community that the government of Pakistan would take steps to help facilitate religious tourism. These steps included "a special tunnel from Guru Nanak Sahib's dargah [shrine] to Gurdwara Janam Asthan, an underground railway to another Gurdwara, and free shuttle services from all main Gurdwaras" (Shah 2019). For Bukhari and the Pakistani government, this was an opportunity to boost their economy through religious tourism as they reach out to communities worldwide and invite them to visit Pakistan. Meanwhile, Virdee stated that "money was not an issue for the Sikh community as they were prepared to lay down their lives 
for their Gurdwara" (Rana 2019). The financial commitment continues the trend, similar to diasporic Sikhs from the 1970s to the early 2000s, of Sikhs fulfilling their wish to visit and preserve Kartarpur and other historical sites in Pakistan. From the efforts initiated by Dhillon and the Sri Nankana Sahib Foundation to the recent tourism and preservation fund established by the Peter Virdee and British Sikhs, there has been a continuous effort by the global Sikh community over the past five decades to preserve and access Sikh heritage sites in Pakistan. Although significant, the narrative of Sidhu and Khan singlehandedly constructing the corridor erases the long history of the work done by diasporic Sikhs. Sikh delegations from the United States and the United Kingdom met with Prime Minister Shaukat Aziz and Yousaf Raza Gillani in 2004 and 2008, respectively (Maini 2008). The common bond between all of these efforts, from the 1970s to the present day, has been the dream of millions of Sikhs since partition. Unfortunately, the groundwork laid by diasporic Sikhs over the past five decades has largely been ignored by both of the governments of India and Pakistan as the political tension constantly hindered any progress.

\section{Rethinking the "Bridge of Peace"}

Based on the new evidence of the role that diasporic Sikhs played in preserving and reviving heritage sites in Pakistan, we must also rethink the understanding of the Kartarpur Corridor as a "bridge of peace". For the global Sikh community, the Kartarpur Corridor was not a politically or economically motivated project, but a religiously motivated one. Despite the projection of the Kartarpur Corridor as a "bridge of peace", there is strong evidence of it being nothing more than an isolated and symbolic gesture to sway the Sikh community with no actual plausibility for it to initiate peace talks. Indeed, the corridor highlights the strategic ulterior motives for India and Pakistan, as politicians from both countries attempt to claim "ownership" of the project, further politicizing the sacred site. Since the partition, the global Sikh community has made several attempts to convince both governments to preserve, maintain, and allow open access to Sikh heritage sites in Pakistan. Despite their pleas, India and Pakistan continuously exert control over the Sikh community's sacred and cultural spaces (Singh 2019a, p. 14). While both countries claim to be allies of the Sikh community and value their wishes, neither has truly shown an uninterrupted commitment to the Sikh community and its sacred sites in Pakistan. However, there have been several moments throughout history that painted India as being hostile to the Sikh community and its gurdwaras, while Pakistan was seen as an ally and protector of the community. This section explores four distinct historical episodes as a basis for exposing the "bridge of peace" as a bridge built on exclusivist structures and weak foundations. In each episode discussed here, issues of the Sikh community's access can be seen as subordinate to domestic and international political compulsions and maneuverings by each of the national governments involved.

\subsection{Indo-Pakistani War of 1971}

Due to the proximity to the border, Darbar Sahib was threatened by the Indo-Pakistani War of 1971. Just outside the gurdwara complex is a missile within a glass encasing. A plaque next to it states the missile was dropped at the site by the Indian Air Force during the 1971 Indo-Pakistan War. Due to a miracle, it fell inside a nearby well, unable to destroy the gurdwara (Rizwan 2018). While the Pakistani Air Force also made an air attack in Punjab, it did not strike near any gurdwaras. The Pakistani government capitalized on the missile by preserving it in a glass case near the complex and painting themselves as allies and protectors of the Sikh community during the renovation process. Shortly after the Indo-Pakistani War of 1971, the Sri Nankana Sahib Foundation began communicating with the Pakistani government to ensure open access and the preservation of gurdwaras in Pakistan. Meanwhile, the Indian government-specifically the Indian Ambassador to the United States at the time, T.N. Kaul—refused to begin a dialogue with Pakistan. Despite the fact that Dhillon used his connections to American politicians to help the U.S.-India relations, Kaul "discouraged Dhillon from visiting Pakistan" and did not want him to engage with Pakistan (Badhwar 1981). Several years later, after ignoring Kaul, Dhillon was able to retain an oral and "detailed written commitment, pledging that 
the Pakistan Government would take care of the shrines and facilitate free access to, and freedom of worship at, these holy places" from President Zia-ul-Haq (ibid., 1981). Dhillon wanted the management and maintenance of these gurdwaras to be under a Sikh institution. At the time, the gurdwaras in Pakistan were under the control of the Evacuee Trust Property Board (ETPB) following the Pant-Mirza Agreement in 1955 (Lal 2014). Despite the commitment by the Pakistani government, nothing came to fruition as President Zia-ul-Haq claimed the Indian government needed to be involved in the process possibly to counteract the secret agreement of 1955 . The Indian government refused to participate in any dialogue with Pakistan in regard to the preservation of and open access to historical Sikh sites in Pakistan.

\subsection{Delhi-Lahore Bus Service and the Kargil War (1999-2001)}

The initial idea of opening access to Kartarpur was proposed by Prime Minister Atal Bihari Vajpayee of India and Prime Minister Nawaz Sharif of Pakistan in February 1999 under the Delhi-Lahore bus diplomacy. While Prime Minister Khan's friendship with Sidhu was the spark that reinvigorated renovations of the corridor, his political rival and former prime minister, Nawaz Sharif, was one of the original architects of the corridor in 1999. However, shortly after signing the Lahore Declaration, a bloodless coup led by the Pakistani military overthrew Sharif due to his relationship with India (Shams 2019). The military leadership felt Sharif was too soft with India as the territorial conflict in Kashmir became hostile during the Kargil War. The military takeover of 1999 resulted in General Pervez Musharraf assuming power as the Chief Executive of Pakistan. For a short time, Musharraf honored the proposed corridor as Pakistan constructed a bridge to allow Sikh pilgrims from India to visit Darbar Sahib, Kartarpur without a visa or passport (The Hindu Net Desk 2019). In December 2000, following the approval of a corridor to Kartarpur, the Guru Nanak Shrine Fellowship wrote letters to Prime Minister Vajpayee and Chief Executive Musharraf in appreciation of their efforts (Attariwala 2001). However, Gobind Singh, the caretaker of Darbar Sahib, claimed that half of the road construction was completed during the Musharraf era "but India never responded" (Rizwan 2018). Over the years, as the geopolitical relations between India and Pakistan worsened, the project was terminated. Although the present Kartarpur Corridor has already overcome several bilateral situations, as the past has shown, Kashmir and other political tensions between the two countries have the capability of revoking the access granted to Sikhs.

\subsection{Khalistan Movement (1984-Present)}

The Pakistani government was eager to avenge the loss of East Pakistan during the Indo-Pakistani War of 1971, which resulted in the creation of Bangladesh as an independent nation. The same year, Dr. Jagjit Singh Chauhan visited Pakistan "as part of an effort to set up a Sikh government" (Pandya 2007). Chauhan placed advertisements in The New York Times, on 12 October 1971, proclaiming the formation of Khalistan. Following the June 1984 attack on Darbar Sahib, Amritsar (commonly referred to as the Golden Temple), the Khalistan movement gained more traction. This became a major concern for the Indian government as Sikhs sought a separate nation, Khalistan. The Pakistani government not only supported the movement but turned its attention to Sikh gurdwaras in Pakistan as they had become sites of political gathering for the Khalistan movement (Khalid 2013, p. 247). During religious festivals in the 1980s, Khalistani leaders such as Chauhan and Ganga Singh Dhillion, began addressing groups of Sikh pilgrims at Gurdwara Janamasthan (Nankana Sahib) with banners reading Khalistan Zindabad, or Long Live Khalistan, posted around the gurdwara (ibid., p. 250). With tensions rising between Khalistani activists and the government of India, key individuals from Pakistan firmly supported Khalistan for several decades. For example, in 1988, the Director-General of the Inter-Services Intelligence (ISI), General Hamid Gul, supported the Khalistan movement and urged Prime Minister Benazir Bhutto to do the same (Aziz 2015). The support for Khalistan from Pakistani officials greatly concerned Indian officials even during the Kartarpur Corridor talks. In November 2018, the same month when the decision to construct the corridor was announced, the Pakistan government allowed Sikhs For Justice 
(SFJ) to open an office in Lahore (Rana 2018). SFJ, a pro-Khalistani organization, is leading the "Khalistan Referendum 2020" campaign and declared the corridor to be a "bridge to Khalistan" (Sahni 2019). The opening of the corridor raised many security concerns, especially for Indian officials. To celebrate the momentous occasion of the opening of the Kartarpur Corridor, the government of Pakistan released an official video and shared it on their social media page (Govt. of Pakistan 2019). Within the four-minute video, there are several seconds in which a "Khalistan 2020" poster appears, referring to a referendum planned for a separate Sikh homeland. Whether the Pakistani government purposefully included the short clip in which a "Khalistan 2020" poster appears to propagate secessionist feelings or not, government officials in India have taken serious issue with it, only further fueling Indo-Pakistani tensions. The Ministry of External Affairs spokesperson Raveesh Kumar "condemn(ed) Pakistan's attempt to undermine the spirit under which the pilgrimage [was] supposed to be undertaken" (Scroll Staff 2019a). Furthermore, they demanded to have it removed as any anti-India propaganda was prohibited during the pilgrimage and the inauguration (Scroll Staff 2019a). The video was just a microcosm of a much larger issue surrounding the opening of the corridor. The Chief Minister of Punjab, Amarinder Singh, protested the corridor as he claims it is part of Pakistan's hidden agenda "on using the corridor to woo the Indian Sikhs to promote the ISI-backed 2020 Khalistan Referendum and creating sleeper cells here" (Scroll Staff 2019b). The concern comes after the Pakistan Railway Minister, Sheikh Rashid, mentioned that the corridor was "the brainchild of Army chief General Qamar Javed Bajwa," which was echoed by Punjab's Police Chief, Dinkar Gupta (Scroll Staff 2020). Questions about General Bajwa and Pakistan's true intentions were also raised when Gopal Singh Chawla, a "prominent pro-Khalistan separatist," was not only present at the ground-breaking ceremony of the corridor, but "seen shaking hands with" General Bajwa despite Chawla being a senior leader of the Pakistan Sikh Gurdwara Parbandhak Committee (Press Trust of India 2018). The Director-General of Inter-Services Public Relations (DG ISPR) for Pakistan, Major General Asif Ghafoor, immediately denied any ulterior motives stating, "Indian media taking a myopic view is selectively showing Mr. Gopal Singh meeting COAS. Army Chief met all guests at the venue irrespective of identity. A peace initiative should not be subjected to propaganda" (DG ISPR 2018). The involvement of Khalistani leaders, such as Chawla, led India to cancel the second round of talks, which were scheduled for 2 April 2019 in Wagah (Press Trust of India 2019d). In order to continue the conversations, the Imran Khan-led Pakistan government removed Chawla from the PSGPC before the 14 July meeting (Singh 2019c). While the Khalistan matter has always been a concern for the Indian government, former Chief Minister of Jammu and Kashmir, Mehbooba Mufti, criticized those trying to portray the corridor as a pro-Khalistan conspiracy as she "fails to understand why allowing people pilgrimage to Guru Nanak Dev Ji's birthplace would assume such undertones" (Scroll Staff 2018). For Sikhs, the corridor was never political, but an answer to a decades-long dream of being able to access historical gurdwaras and sites in Pakistan. Yet, the corridor is unable to serve as a "bridge of peace" until the ongoing tensions between India and Pakistan are resolved. The corridor was not the first step to peace talks between the neighboring rivals, but an isolated incident with ulterior motives for the two countries.

\subsection{Kashmir, Citizenship Amendment Bill, Nankana Sahib, and False Peace}

In May 2017, the former Minister of State for External Affairs for India, Shashi Tharoor, proclaimed that the corridor would not be beneficial because of the political climate. While acknowledging the positive impact that the corridor would have on religious tourism, Tharoor's reservations, coming just 18 months before the foundation stone for the corridor was laid, came due to the fact that "Pakistani agencies are regularly beheading Indian soldiers" (Dhaliwal 2017). The incident mentioned by Tharoor was the beheading of two Indian soldiers along the Line of Control in Jammu and Kashmir earlier that month (Bhat 2017). Tharoor said that he would advocate for the corridor "only when the situation is normal" (Dhaliwal 2017). Although the governments of India and Pakistan were able to set their differences aside and come to a compromise to open the corridor, the tension between the two countries remains. In 2016, the state of Jammu and Kashmir was recognized as the most militarized land in the 
world (Singh 2016b). The territorial conflict over Kashmir, which began with the partition in 1947, shows no sign of slowing down. Shortly before the corridor, on 5 August 2019, Kashmir was put on lockdown and was revoked of Article 370 and Article 35a by the Indian government which gave special status to the state of Jammu and Kashmir. This included the "power to have its own constitution, flag and autonomy over all matters, save for certain policy areas such as a foreign affairs and defense" (Suri 2019). Nevertheless, Prime Minister Khan reassured his commitment to the Kartarpur Corridor as the government of Pakistan isolated the project from the tensions that arose after the annulment of Article 370 (Yousaf 2019). Immediately after the corridor, in December 2019, the Indian government passed the anti-Muslim Citizenship Amendment Bill—the first sign of the "bridge of peace" being a superficial bridge. The bill was strongly condemned by Prime Minister Khan who claimed Narendra Modi's supreme Hindutva mindset would "violate all norms of international human rights law and bilateral agreements with Pakistan ... India is working towards making a Muslim majority state into minority in Jammu and Kashmir (JK) by bringing in Hindu people and settling them in the valley" (Press Trust of India 2019b; Sabrang India 2019). With the conflict between the neighboring countries based on religion, the Sikh community was once again caught in the crossfire. A local incident from Nankana Sahib in late August 2019-when the daughter of a Sikh "granthi" (priest) was allegedly kidnapped, forcibly converted to Islam, and forced to marry a Muslim man-was brought to the international limelight in January 2020 following vandalism at Nankana Sahib. For India, this incident was an opportunity to justify the Citizenship Amendment Bill. With India being heavily criticized for the bill and anti-Muslim violence, the incident allowed them to shift the criticism onto Pakistan by labeling it a "jihadist and extremist country" that manipulated the Sikh community with the Kartarpur Corridor (New Desk 2020). Although Prime Minister Khan condemned the vandalism and claimed it went against his vision for Pakistan, he also used it as an opportunity to condemn the "Modi's RSS vision" and the ongoing anti-Muslim violence in India (Ahmad 2020). The corridor continues Pakistan's trend of "actively promoting its cultural soft power" by assisting religious minorities (Singh 2019a, p. 9). India followed a similar trajectory, despite its history of persecution of minority groups, by offering refugee to Afghan Sikhs fleeing persecution in 2020 (Bainiwal 2020). While the Kartarpur Corridor was extremely significant, it is nothing more than a symbolic, isolated event that occurred "without any systematic changes" in the present structures that are "premised upon an exclusive Muslim identity [in Pakistan], standing in opposition to a non-Muslim Hindu India" (Khalid 2020, emphasis added). This forces one to ask what "peace" does the "bridge of peace" offer as the current exclusivist structures in India and Pakistan continue to ignore the wishes of the Sikh community unless it benefits them? Talks of a peace corridor to the Darbar Sahib, Kartarpur consistently surfaced for several years, yet it was "held hostage by politics" (Khalid 2017b). As long as the ongoing political tension is present and the current structures remain, they have the ability to strip Sikhs of access to Darbar Sahib once again. Unfortunately, the days of viewing Darbar Sahib from a telescope from Dera Baba Nanak, three kilometers away, may be one incident away.

\section{Conclusions}

Since the partition in 1947, generations of Sikhs across the globe have been praying for open access to historical sites in Pakistan. From losing access to historical sites in Pakistan to decades-long activism, the Sikh community remained resilient. While thousands of Sikhs died praying for the moment these prayers would be answered, the uncertain political dynamic between Pakistan and India continues to be a serious concern. For the two countries, the opening of the corridor was a political and/or economic move as it serves as a tool for both governments to control pilgrimage and attract tourists. Meanwhile, for the global Sikh community, this supersedes all matters of politics and economics as it is an opportunity for unrestricted access to some of their most historical sites. Sikhs in the diaspora have been more invested in preserving and maintaining historical Sikh sites in Pakistan than the Indian and Pakistani governments. On multiple occasions, diasporic Sikhs have opened lines of communication with both governments, but the political tensions never allowed anything to 
come to fruition. Although the friendship between the cricketers-turned-politicians across the border deserves credit for officially opening the Kartarpur Corridor, friendships and agreements between the neighboring countries struggle to remain as politicians come and go. Khan's "first big opposition as the Prime Minister" came following the Kartarpur Corridor (SNS Web 2019). Maulana Fazlur Rehman, president of the Jamiat Ulema-e-Islam (JUI-F) political party, accused Khan of allowing the corridor to happen while India handed over the Babri Mosque to Hindus while a leader of the Pakistan Muslims League-Nawaz and an ally of Rehman, Ahsan Iqbal, called Khan's move to allow Indians to enter without a passport a huge mistake (BR Web Desk 2019; Press Trust of India 2019c). Meanwhile, in India, Sidhu has been criticized for his relationship with Khan. A spokesperson for the current ruling political party of India, the Bharatiya Janata Party, condemned Sidhu for his remarks praising Khan, claiming it was an attempt to place Khan on a higher pedestal than India (Press Trust of India 2019a). However, the criticism for Sidhu was not limited to the opposition political party and non-Sikhs. Captain Amarinder Singh, Chief Minister of Punjab, and Charanjit Singh Channi, Punjab cabinet minister, both criticized Sidhu on his dealings with Khan and Pakistan on separate occasions (Hindustan Times Correspondent 2019; Sethi 2019). Not only are Khan and Sidhu facing criticism for their decision, but individuals from both sides have ulterior motives for the corridor. With the ongoing attack on the Indian Muslim population, whether in Kashmir or through legislation such as the Citizenship Amendment Bill, the Indian government aims to not only secure the Sikh votes but also continue to please the Sikh community with the corridor. Meanwhile, the corridor helps Pakistan boost its economy through religious tourism while potentially being able to support the Khalistan movement. Throughout the entire process, as politicians and media outlets across the border continue to criticize the other's motives, the importance of access to historical heritage sites for the Sikh community is undermined. The "bridge of peace" may be temporary as the project was completely isolated. Therefore, with the ongoing tensions and any upcoming elections, the Kartarpur Corridor continues to be held hostage by the uncertainty of politics between India and Pakistan. What we know for certain is that the threat of closing the corridor due to political tensions may always remain, but so will the drive of the global Sikh community to keep these sites intact and accessible.

Funding: This research received no external funding.

Acknowledgments: I am grateful to Gurcharanjit Singh Attariwala and his daughter, Parmela, who shared Attariwala's journey with me to present at the UC Riverside International Sikh Studies Conference in 2019. Before this conference, not much was known about the role of diasporic Sikhs in preserving Darbar Sahib, Kartarpur. Since the conference in 2019, Attariwala has continued to share stories with me about his work in preserving Darbar Sahib. I am also thankful to Gurcharan Singh Bhuchar, Harbans Lal, Amardeep Singh, and Dalvir Singh Pannu for speaking to me about their work which allowed me to capture a better image of the work done by diasporic Sikhs.

Conflicts of Interest: The author declares no conflict of interest.

Dedication: I dedicate this article to my Nana Ji (maternal grandfather), Charan Singh "Sangatpura", the prominent Sikh leader from Hong Kong and member of the Sri Nankana Sahib Foundation mentioned in the article. He dedicated his life to the Sikh community and worked on many different causes including the yatras (pilgrimages) to Pakistan. For decades, Nana Ji did ardas for khule darshan didar. Unfortunately, like countless others, he was unable to see the ardas fulfilled. I felt it was only appropriate to preserve his story and acknowledge the numerous sevadars who worked behind the scenes for decades, paving the road for future generations. Far too often, these sevadars are excluded from the dominant narratives. Thank you to all of those sevadars.

\section{References}

Ahmad, Imtiaz. 2020. 'Not My Vision': Imran Khan on Nankana Sahib Attack. Hindustan Times. Available online: https://www.hindustantimes.com/india-news/not-my-vision-imran-on-attack/story-gGHa69w2fc 2piwIn11ZTJM.html (accessed on 28 August 2020).

Attariwala, Gurcharan Singh. 2001. Guru Nanak Shrine Fellowship, In the author's possession.

Attariwala, Gurcharan Singh. 2019a. Personal conversation with author. May 2.

Attariwala, Parmela. 2019b. Personal conversation with Gurcharan Singh Attariwala. April 23. 
Aziz, Shaikh. 2015. A Leaf from History: The Rise and Fall of the Khalistan Movement. Dawn. Available online: https://www.dawn.com/news/1193181 (accessed on 10 August 2020).

Badhwar, Inderjit. 1981. I don't Need Zia or the CIA to Tell Me What to Do: Ganga Singh Dhillon. India Today. Available online: https://www.indiatoday.in/magazine/international/story/19811130-i-am-an-agent-of-gurunanak-ganga-singh-dhillon-773466-2013-10-25 (accessed on 27 July 2020).

Bainiwal, Tejpaul Singh. 2020. With Trump's Failure to Protect Religious Minorities, Afghan Hindus and Sikhs Face an Uncertain Future in India. Religion Dispatches. Available online: https://religiondispatches.org/ with-trumps-failure-to-protect-religious-minorities-afghan-hindus-and-sikhs-face-an-uncertain-futurein-india/ (accessed on 15 September 2020).

Bharti, Vishav. 2018. Access First Promised in 1969. The Tribune. Available online: https://www.tribuneindia.com /news/archive/punjab/access-first-promised-in-1969-690075 (accessed on 10 September 2020).

Bhat, Anil. 2017. Slain Indian Soldiers Might Have Fallen into a Death Trap Set up by Pakistani BATs. Mint. Available online: https://www.livemint.com/Politics/oturqz0uQmDBKDs7pjG3oM/Slain-Indian-soldiers-m ight-have-fallen-into-a-death-trap-se.html (accessed on 27 August 2020).

Bhuchar, Gurcharan Singh. 2020. Telephone conversation with author. August 11.

BR Web Desk. 2019. Fazl Criticises Govt for Opening Kartarpur Corridor. Business Recorder. Available online: https://www.brecorder.com/2019/11/10/543159/fazl-criticises-govt-for-opening-kartarpur-corridor/ (accessed on 16 August 2020).

DG ISPR. 2018. Indian Media Taking a Myopic View Is Selectively Showing Mr. Gopal Chawla Meeting COAS. Twitter. November 28. Available online: https://twitter.com/OfficialDGISPR/status/1067751304641093633 (accessed on 21 August 2020).

Dhaliwal, Ravi. 2017. Corridor Connecting India with Kartarpur Sahib Shrine in Pak Ruled out. The Tribune. Available online: https://www.tribuneindia.com/news/archive/features/-corridor-connecting-india-with-kar tarpur-sahib-shrine-in-pak-ruled-out-400962 (accessed on 19 August 2020).

Express News Service. 2018. Visas for Pilgrims: 15 Shrines in Pak, 5 in India under Protocol. The Indian Express. Available online: https://indianexpress.com/article/explained/explained-snippets-fact-check-ground-reality -15-shrines-in-pak-5-in-india-under-protocol-for-pilgrim-visas-5466033/ (accessed on 19 August 2020).

Govt. of Pakistan. 2019. Official Song of Kartarpur Corridor Opening Ceremony. Twitter. November 4. Available online: https://twitter.com/pid_gov/status/1191417856203927552 (accessed on 24 August 2020).

Goyal, Divya. 2019. Before Kartarpur Corridor, a Struggle of Five Decades to Reopen, Restore Gurdwara. The Indian Express. Available online: https://indianexpress.com/article/india/before-kartarpur-corridor-a-stru ggle-to-reopen-restore-6105608/ (accessed on 27 August 2020).

Grewal, Jagtar Singh. 1969. Guru Nanak in History. Chandigarh: Panjab University.

Grewal, Jagtar Singh. 1990. The New Cambridge History of India: The Sikhs of the Punjab. Cambridge: Cambridge University Press.

Hindustan Times Correspondent. 2019. 'Evil Plan Exposed': Amarinder Singh on Pak Minister's Kartarpur Remarks. Hindustan Times. Available online: https://www.hindustantimes.com/india-news/pak-minister-s-k artarpur-disclosure-exposes-islamabad-s-nefarious-designs-says-capt-amarinder/story-qdk1RlpkNnzu CISjidOVKP.html (accessed on 12 August 2020).

Khalid, Haroon. 2013. A White Trail: A Journey into the Heart of Pakistan's Religious Minorities. Chennai: Westland Ltd.

Khalid, Haroon. 2017a. How Nanak's Muslim Followers in Pakistan Never Abandoned Kartarpur Sahib, His Final Resting Place. Scroll. Available online: https://scroll.in/article/857302/how-nanaks-muslim-followers-i n-pakistan-never-abandoned-kartarpur-sahib-his-final-resting-place (accessed on 26 August 2020).

Khalid, Haroon. 2017b. Pakistan's Sikh Heritage Could Be a Bridge to Peace, if Not Bound by Its Hostile Ties with India. Scroll. Available online: https://scroll.in/article/842950/pakistans-sikh-heritage-could-be-a-bridge-topeace-if-not-bound-by-its-hostile-ties-with-india?fbclid=IwAR2f0LieIF1EtHS9E7TBm1hecG3QYp2wm hVGjYw14NYSBEvZv0JzKLfwngA (accessed on 26 August 2020).

Khalid, Haroon. 2020. Nankana Sahib Is the Undoing of Kartarpur's Movement Towards an Inclusive Pakistani Identity. The Wire. Available online: https://thewire.in/religion/kartarpur-nankana-sahib-attack (accessed on 28 August 2020). 
Lal, Harbans. 2014. He Served the Sikh Nation with Passion and Dedication: Ganga Singh Dhillon. SikhNet. Available online: https://www.sikhnet.com/news/he-served-sikh-nation-passion-dedication-ganga-singhdhillon (accessed on 25 July 2020).

Maini, Tridivesh Singh. 2008. Pakistan Open to 'Visa-Free' Sikh Pilgrimage. The Indian Express. Available online: http://archive.indianexpress.com/news/pakistan-open-to-visafree-sikh-pilgrimage/297316/ (accessed on 10 September 2020).

Ministry of External Affairs. n.d. Protocol on Visits to Religious Shrines, September 14, 1974. Government of India. Available online: https://mea.gov.in/bilateral-documents.htm?dtl/6199/Protocol+on+visits+to+Religious+Sh rines (accessed on 2 September 2020).

New Desk. 2020. India Trying to Justify Killing Citizens by Condemning Nankana Incident. Global Village Space. Available online: https://www.globalvillagespace.com/india-trying-to-justify-killing-citizens-by-condemnin g-nankana-incident/ (accessed on 24 August 2020).

Oberoi, Harjot. 1994. The Construction of Religious Boundaries: Culture, Identity, and Diversity in the Sikh Tradition. Delhi: Oxford Univerity Press.

Pandya, Haresh. 2007. Jagjit Singh Chauhan, Sikh Militant Leader in India, Dies at 80. The New York Times. Available online: https:/www.nytimes.com/2007/04/11/world/asia/11chauhan.html?_r=1\&fta=y\&oref=slogin (accessed on 30 August 2020).

Pannu, Dalvir Singh. 2019. The Sikh Heritage: Beyond Borders. San Jose: Pannu Dental Group.

Pannu, Dalvir Singh. 2020. Telephone conversation with author. September 3.

Petrie, David. 1970. Secret C.I.D. Memorandum on Some Recent Developments in Sikh Politics. In The Panjab Past and Present. Punjab: Punjabi University, vol. 4, pp. 301-79.

Press Trust of India. 2018. Pro-Khalistan Leader Seen Shaking Hands with Pak Army Chief. The Tribune. Available online: https://www.tribuneindia.com/news/archive/punjab/pro-khalistan-leader-seen-shaking-hands-wit h-pak-army-chief-690327 (accessed on 25 August 2020).

Press Trust of India. 2019a. BJP Attacks Navjot Sidhu For Praising Imran Khan at Kartarpur Event. NDTV. Available online: https://www.ndtv.com/india-news/bjp-attacks-navjot-sidhu-for-praising-imran-khan-atkartarpur-event-2130453 (accessed on 18 August 2020).

Press Trust of India. 2019b. Pakistan Condemns CAB, Calls It India's Attempt to Interfere in Neighbouring Countries. Financial Express. Available online: https://www.financialexpress.com/india-news/pakistan-cond emns-cab-calls-it-indias-attempt-to-interfere-in-neighbouring-countries/1789681/ (accessed on 26 August 2020).

Press Trust of India. 2019c. Pakistan PM Says Kartarpur Corridor Ready to Welcome Sikh Pilgrims for Guru Nanak's 550th Birthday. News18. Available online: https://www.news18.com/news/world/pakistan-pm-imran-khan-s ays-kartarpur-corridor-ready-to-welcome-sikh-pilgrims-for-guru-nanaks-550th-birthday-2371863.html (accessed on 15 August 2020).

Press Trust of India. 2019d. Pak Removes Controversial Khalistani Separatists from Sikh Committee. The Economic Times. Available online: https:/economictimes.indiatimes.com/news/politics-and-nation/ pak-removes-controversial-khalistani-separatists-from-sikh-committee/articleshow/70214511.cms (accessed on 21 August 2020).

Rana, Yudhvir. 2018. Pak Allows SFJ to Open 'Referendum 2020' Office in Lahore. Times of India. Available online: https:/timesofindia.indiatimes.com/city/chandigarh/pak-allows-sfj-to-open-referendum-2020-of fice-in-lahore/articleshow/66758012.cms (accessed on 11 August 2020).

Rana, Yudhvir. 2019. UK's Sikh Businesses to Invest 500 mn Pounds in Religious Projects in Pak. Times of India. Available online: https:/timesofindia.indiatimes.com/india/uks-sikh-businesses-to-invest-500-mn-pounds-i n-religious-projects-in-pak/articleshow/69738216.cms (accessed on 3 August 2020).

Rizwan, Sheharyar. 2018. Footprints: The Borders of Man. Dawn. Available online: https://www.dawn.com/news/ 1433605 (accessed on 4 September 2020).

Sabrang India. 2019. Pakistan's Minorities, Hindus, Sikhs \& Christians React to India's CAA/CAB. Sabrang. Available online: https://sabrangindia.in/article/pakistans-minorities-hindus-sikhs-christians-react-indiascaacab (accessed on 24 August 2020).

Sahni, Ajai. 2019. A Road Fraught with Risks. The Tribune. Available online: https://www.tribuneindia.com/news/ archive/comment/a-road-fraught-with-risks-756758 (accessed on 12 August 2020). 
Sandhu, Charan Singh "Sangatpura". n.d. Sri Nankana Sahib Foundation, Private collection of Tejpaul Singh Bainiwal. Scroll Staff. 2018. Kartarpur Corridor Will Start Reconciliation Process between India and Pakistan, Says Mehbooba Mufti. Scroll. Available online: https://scroll.in/latest/903919/kartarpur-corridor-will-start-reconciliation-pro cess-between-india-and-pakistan-says-mehbooba-mufti (accessed on 24 August 2020).

Scroll Staff. 2019a. Kartarpur Corridor: Remove Welcome Video Showing Khalistani Separatists, India Tells Pakistan. Scroll. Available online: https:/scroll.in/latest/942974/kartarpur-corridor-remove-welcome-videoshowing-khalistani-separatists-india-tells-pakistan (accessed on 24 August 2020).

Scroll Staff. 2019b. Khalistani Leaders, Sikh Referendum Date Seen in Pakistan's Kartarpur Welcome Video. Scroll. Available online: https://scroll.in/latest/942840/khalistani-leaders-sikh-referendum-date-seen-in-pakistanskartarpur-welcome-video (accessed on 24 August 2020).

Scroll Staff. 2020. Kartarpur Corridor Is a 'Potential Threat' to National Security, Says Punjab Police Chief: Report. Scroll. Available online: https://scroll.in/latest/953962/kartarpur-corridor-is-a-potential-threat-to-national-s ecurity-says-punjab-police-chief-report (accessed on 24 August 2020).

Sethi, Chitleen. 2019. Sidhu's Kartarpur Speech Has not Only Gone Viral, It Just Resurrected His Political Career. The Print. Available online: https://heprint.in/politics/sidhus-kartarpur-speech-has-not-only-gone-viral-itjust-resurrected-his-political-career/320993/ (accessed on 13 August 2020).

Shah, Murtaza Ali. 2019. Sikh Tycoon Announces $£ 500$ Million Fund for Pakistan Gurdwaras. The News. Available online: https://www.thenews.com.pk/latest/483612-sikh-tycoon-announces-500-million-fund-for-pakistan -gurdwaras (accessed on 7 August 2020).

Shams, Shamil. 2019. Why Kartarpur Corridor Is unlikely to Defuse India-Pakistan Tensions. Deutsche Welle. Available online: https://www.dw.com/en/why-kartarpur-corridor-is-unlikely-to-defuse-india-pakistan-te nsions/a-51166467 (accessed on 8 September 2020).

Sikh Channel. 2019. 180919 The Virdee Foundation (London). Sikh Channel. September 18. Available online: https://www.youtube.com/watch?v=IAQcXE-TNM0 (accessed on 5 August 2020).

Singh, Pashaura. 2006. Life and Work of Guru Arjan. Oxford: Oxford University Press.

Singh, Roop. 2012. Edicts of Sri Akal Takht Sahib. Amritsar: Singh Brothers.

Singh, Amardeep. 2016a. Lost Heritage: The Sikh Legacy in Pakistan. New Delhi: Himalayan Books.

Singh, Rani. 2016b. Kashmir: The World's Most Militarized Zone, Violence after Years of Comparative Calm. Forbes. Available online: https://www.forbes.com/sites/ranisingh/2016/07/12/kashmir-in-the-worlds-most-m ilitarized-zone-violence-after-years-of-comparative-calm/\#5d42b07e3124 (accessed on 30 August 2020).

Singh, Amardeep. 2017. The Quest Continues, Lost Heritage. The Sikh Legacy in Pakistan. New Delhi: Himalayan Books.

Singh, Gurharpal. 2019a. The control of sacred spaces: Sikh shrines in Pakistan from the partition to the Kartarpur Corridor. In Sikh Formations: Religion, Culture, Theory. Oxon: Taylor and Francis Online. [CrossRef]

Singh, Jaswinder. 2019b. Meet Writer of Ardaas 94 Years old man|Sikh Religion. News Today Live. May 22. Available online: https://www.youtube.com/watch?v=xev5V0OVY1Y (accessed on 18 August 2020).

Singh, Varinder. 2019c. Pak Drops Pro-Khalistan ACTIVISt Gopal Chawla, Others from PSGPC. The Tribune. Available online: https://www.tribuneindia.com/news/archive/punjab/pak-drops-pro-khalistan-activist-go pal-chawla-others-from-psgpc-801600 (accessed on 22 August 2020).

Singh, Amardeep. 2020. Personal conversation with author. September 11.

SNS Web. 2019. Pak Prime Minister Receives 48-hour Ultimatum from Opposition to Resign. The Statesma. Available online: https:/www.thestatesman.com/world/pak-prime-minister-receives-48-hour-ultimatum-f rom-opposition-to-resign-1502819148.html (accessed on 21 August 2020).

Suri, Manveena. 2019. Article 370: How India's Special Status for Kashmir Works. CNN. Available online: https: //www.cnn.com/2019/08/05/asia/article-370-india-explainer-intl/index.html (accessed on 29 August 2020).

The Hindu Net Desk. 2019. A Timeline of the Kartarpur Corridor. The Hindu. Available online: https://www. thehindu.com/news/national/watch-a-timeline-of-the-kartarpur-corridor/article29960748.ece (accessed on 7 September 2020).

United Nations News. 2020. Pakistan-India Crossing Is a 'Corridor of Hope', UN Chief Says, Wraps up Visit with Call for Interfaith Dialogue. Available online: https://news.un.org/en/story/2020/02/1057621 (accessed on 28 August 2020). 
Yousaf, Kamran. 2019. Pakistan to Invite Former Indian PM to Kartarpur Corridor Inauguration. The Express Tribune. Available online: https:/tribune.com.pk/story/2068827/1-pakistan-invite-ex-india-pm-inauguratekartarpur-corridor (accessed on 20 August 2020).

Publisher's Note: MDPI stays neutral with regard to jurisdictional claims in published maps and institutional affiliations.

(C) 2020 by the author. Licensee MDPI, Basel, Switzerland. This article is an open access article distributed under the terms and conditions of the Creative Commons Attribution (CC BY) license (http://creativecommons.org/licenses/by/4.0/). 